\title{
Congressional Lobby, Foreign Policy, and Trade Agreements in Democratic Chile
}

\author{
Ricardo Gamboa \\ Institute of International Studies \\ University of Chile \\ rgamboa@uchile.cl
}

Carolina Segovia

School of Political Science

Universidad Diego Portales

carolina.segovia@udp.cl

This paper studies the participation and influence of IGs on Chilean Foreign Policy between 1990 and 2014 , in light of the main results provided by academic literature on this topic. To do this, we created an original database of 590 international treaties that Chile subscribed in the period, and analyzed it using quantitative techniques. The paper argues, first, that the participation of IGs in the matter is rather low, and that the participation pattern is highly unbalanced. Second, our preference attainment analysis underlies that the agreement between the preferences of business IGs and the content of treaties is no greater than that of other type of IGs.

Research for this paper was funded by the Swiss State Secretariat for Economic Affairs under the SECO / WTI Academic Cooperation Project, based at the World Trade Institute of the University of Bern, Switzerland. SECO working papers are preliminary documents posted on the WTI website (www.wti.org) and widely circulated to stimulate discussion and critical comment. These papers have not been formally edited. Citations should refer to a "SECO / WTI Academic Cooperation Project" paper with appropriate reference made to the author(s). 


\title{
Congressional Lobby, Foreign Policy, and Trade Agreements in Democratic Chile
}

\section{SECO/WTI ACADEMIC COOPERATION \\ PROJECT WORKING PAPER}

\author{
Ricardo Gamboa ${ }^{1}$ Carolina Segovia ${ }^{2}$
}

\begin{abstract}
This paper studies the participation and influence of IGs on Chilean Foreign Policy between 1990 and 2014, in light of the main results provided by academic literature on this topic. To do this, we created an original database of 590 international treaties that Chile subscribed in the period, and analyzed it using quantitative techniques. The paper argues, first, that the participation of IGs in the matter is rather low, and that the participation pattern is highly unbalanced. Second, our preference attainment analysis underlies that the agreement between the preferences of business IGs and the content of treaties is no greater than that of other type of IGs.
\end{abstract}

Key Words: Interest groups; Foreign Policy; Free Trade Agreements; Chile.

\footnotetext{
${ }^{1}$ Ricardo Gamboa holds a Ph.D. in Political Science from the University of Tübingen, Germany. Associate Professor, Institute for International Studies, University of Chile. ${ }^{2}$ Carolina Segovia is Ph.D. in Political Science, University of Michigan, U.S. Associate Professor, School of Political Science, Universidad Diego Portales.
} 


\title{
Congressional Lobby, Foreign Policy, and Trade Agreements in Democratic Chile
}

\author{
Ricardo Gamboa, Universidad de Chile \\ Carolina Segovia, Universidad Diego Portales
}

\section{Research Problem}

Interest groups play a central role in a democratic polity. In this context, in political science an important line of research focuses on different issues related to the organization of interest groups (IGs), as well as on the role they play in the decision making process (Baumgartner \& Leech 1998; Baumgartner et. al. 2009; Binderkrantz et. al. 2014; Dür \& De Bièvre 2008). The literature that concentrates on their role in decision making process (DMP) touches on different related issues, such as the patterns of participation of IGs, their influence on public policy decisions, and the determinants of that influence. As a result of this effort, abundant evidence on the topic is available for analytical purposes.

IGs role in Foreign Policy has also been thoroughly analyzed by comparative research, which has concentrated mainly on the case of the US, examining the activities of IGs and their effects at different policy levels (Jacobs \& Page, 2005; Keohane \& Milner 1996; McKormick 2012; Milner 1997; Rogowski, 1989). In the case of the European Union (EU), even though the role of IGs in DMP has been largely analyzed, in the specific case of Foreign Policy the academic attention has been rather scarce (Shapovalova, 2015: 45; Voltolini, 2013).

In the case of Chile, even though many scholars have made interesting contributions, a more comprehensive research on the issue is still lacking (Gamboa et. al. 2016). This gap is even deeper in the case of Foreign Policy, and particularly in that of Foreign Trade Policy, even though the latter has occupied a central role in the last 27 years in Chile (Direcon 2009). Moreover, although useful for understanding important decisions on Foreign Policy, this literature has mainly concentrated on specific issues or cases, having neglected a more systematic approach (Bull 2008; Direcon 2009; Gamboa 
2013; Herreros 2010). Therefore, the role of IGs in Foreign Policy remains understudied. If we want to better understand how Chilean Foreign Policy is made, and how the civil society participates in it, more research on the topic is needed.

This paper aims to contribute to fill this gap, by analyzing the participation and influence of IGs on Chilean Foreign Policy between 1990 and 2014. To carry out the study, first, we examine the participation of IGs in the parliamentary discussion of the international treaties Chile signed in this period. Second, we analyze the issue of the influence of IGs on Foreign Policy decisions using the methodology of preference attainment. Basically, it consists in identifying the preferences expressed by IGs before Congress with regard to the International treaties, and comparing them with the approved texts. In this context, we will pay special attention on the role of IGs with regard to Foreign Trade Policy, which is an area where IGs have been very active (Gamboa 2013).

To accomplish this task, we created an original database of 590 international treaties (of any kind) that Chile subscribed between 1990 and $2014^{3}$. This contains information about the IGs that participated in their discussion, and the opinions they expressed. We started in 1990 because it was the year of democratic restoration. Also, 2014 is the year of the last completed presidential term.

We argue as follows. First, the participation of IGs in the discussion of international treaties is rather low, as a very high percentage of treaties (more than $85 \%$ ) are analyzed in congress without IGs intervention. Free Trade Agreements (FTAs) are the type of treaty that shows highest levels of participation on average (even though it is still low). Second, that the general pattern of distribution of IGs participation by type of group is highly unbalanced. This, because business IGs account for more than two thirds of it. This imbalance is even higher when we look the congressional debate of treaties dealing with economic matters, and especially at FTAs. At the same time, however, the participation is more balanced when only non---economic treaties are considered. Third, our preference attainment analysis underlies that the agreement between the preferences of business IGs and the content of treaties is not greater than that of other type of IGs.

\footnotetext{
${ }^{3}$ The database was built with information obtained from www.congreso.cl.
} 
This work is divided into five sections. First, we describe our analytical frame, which bases on the main comparative research on the issue. Second, we explain the institutional setting of Foreign Policy formulation in Chile, and the mechanisms the IGs can use in order to exert influence on it. Third, we outline our methodological strategy. Fourth, we present and discuss our main results. Lastly, we conclude.

\section{Analytical Frame}

The role the $1 G s^{4}$ play in the DMP has been extensively analyzed in Political Science, especially with regard to the cases of the United States (US), the European Union (EU), and some European countries, like Germany or Denmark (Baumgartner \& Leech 1998; Binderkrantz et. al. 2014; Dür 2008; Dür \& Matteo, 2012; Klüver 2012; Yackee \& Yackee 2006). The research has focused on different related topics, such as the processes of group mobilization, the organizational characteristics of the IGs, the strategies they deploy to promote their interest vis---a---vis diverse institutions to influence policy decisions, and the determinants of that participation and influence (Baumgartner \& Leech 1998).

With regard to the first topic addressed in this work, participation and how it distributes among types of group, academic research has made significant progress. In the case of the US, there is abundant evidence that points out that business IGs, in general terms, are more active in DMP than other groups, like citizens, professionals, labor organizations, or public institutions (Baumgartner \& Leech 2001: 1194; Baumgartner et. al 2009: 9). In the case of the EU the evidence reveals a similar pattern (Klüver 2012: 1123; Dür \& Matteo, 2012; Binderkrantz et. al. 2014), even though the predominance of business seems to be lower than in the case of the US (Gamboa et al. 2016: 145).

\footnotetext{
${ }^{4}$ There is an extensive discussion on the concrete meaning of the concept of interest group (Baroni et al. 2014). Here we take the definition used by Gamboa and his colleagues (2016), which is very adequate for this work's purposes. An IG will be defined as any formally existent organization that defends an interest in that capacity before Congress. Therefore, we exclude those people who participate in legislative debates on their own account (even when they belong to an IG), as well as political parties and state organizations.
} 
Scholars have also analyzed if this pattern holds when we distinguish by policy areas. The evidence shows that when we consider only "economic" issues, the predominance of business IG is even greater. But, when we look only at "non--economic" policy areas, the distribution of participation is notably more balanced among types of IG. (Binderkrantz et. al. 2014: 889). According to data collected by Gamboa et. al (2016), this is also the case of Chile. In their study they recorded 1777 interventions of IGs in 571 law making processes carried out in Congress between 2006 and 2014. 977 of the interventions were made during the discussion of economic bills, and among them more than $50 \%$ by business IGs. But, when only non--economic bills are considered, business IGs accounted for only $25 \%$ of 800 participations, even less than professional groups (Gamboa et. al 2016: 154).

Our second research interest refers to that of IGs influence on policy decisions. Even though this is an issue of major importance, and despite significant efforts, it is an area where until now academic research has made fewer advances. A Dür notes, this is due to different reasons, like the fact that it is exerted through many different channels, the existence of the phenomena of counteractive lobbying, and that influence is wielded at different stages of the DMP (Dür 2008 561: see also Helboe 2013).

In spite of these difficulties, scholars have taken up the challenge of developing methods to measure influence empirically. Three main strategies have been designed (Dür 2008). The first is process tracing, which consists of detailed studies of a one or few specific decision processes, identifying the IGs that participate, their strategies and influence attempts, and finally evaluating if the decisions reflect their preferences or not. Simply put, as Dür says, this is about to "try to uncover the steps by which causes affect outcomes" (2008: 562). Having these features, this is a method clearly more appropriate for case studies, that allow for in--depth analysis of cases. The second is known as attributed influence, and bases on surveys to experts, or to organizations leaders as a mean to determine the degree of influence of the IGs in the political system. An example of the use of this method is the work done by Jacobs and Page (2005), which relies on surveys to figure out which IGs exert more influence on US Foreign Policy. The third method is 6 preference attainment, in which "the outcomes of political processes are compared 
with the ideal points of actors" (Dür 2008: 566). Therefore, according to this methodology, the higher the level of agreement between IG preferences and the final decisions, the more influential that IG is considered.

Each method has strengths and weaknesses, being more or less useful depending on the type of research one wants to conduct. Considering the objectives of this paper, we choose to use a preference attainment strategy, because it is which better allows us to compare IGs Foreign Policy preferences and policy decisions (treaties`contents), and also to obtain a measure of influence considering a large $\mathrm{N}$.

The evidence generated by comparative research is inconclusive about which type of IG is more influential in DMP. On the one hand, studies in the US have shown that business IGs exerts more influence in DMP than other groups, for example when administrative decisions are considered (Yackee \& Yackee 2006). The same has been argued in the case of US Foreign Policy, where the evidence reveals that they are more influential than labor unions and expert communities (Jacobs \& Page 2005: 120). On the other, however, scholars have shown that business IGs not always "get what they want", and that their influence capacity is dependent upon other factors, as the counteractive Lobby they face in the specific policy processes (Hojnacki et. al. 2015), or the kind of objective they pursue ${ }^{5}$ (Godwin et. al. 2013: 102). In the same vein, studies in the EU suggest that in the EU "industry wins too but so do citizen groups and foundations", and then no pattern can be identified (Mahoney 2007: 54). In the case of Chile, the analysis of Gamboa et. al demonstrates that the business IGs, contrary to the initial expectations, do not get more than other groups in DMP (2016: 157).

This brief account of the findings of the academic research provides a useful guide for carrying out this work. First, considering the participation trends in DMP, it shows that there is an apparent clear trend: that the business IG participates more than other types of groups in it. Second, that we should expect that business IGs get no more than other groups in DMP, that is, that they are not more influential than other. We will get back to these issues when we analyze our results.

\footnotetext{
${ }^{5}$ For example, it is argued that when one pursues the maintenance of the status quo has more chances to get it, than when one demand a major change of it.
} 


\section{Mechanisms of IGs participation in the Chilean Foreign Policy Making Process.}

As in most presidential systems, the Chilean Constitution stipulates that one special power of the president is to conduct the political relations with other countries (art. 32 n. 15). Accordingly, to carry out negotiations, to conclude them, and to subscribe treaties with other foreign actors are an exclusive power of the president (Art. 32 no. 15). Nevertheless, those international agreements can enter into force only if ratified by congress (arts. 32 no. 15 and 54 no. 1). The quora required for the approval depends on the content of the specific treaties (it can go from simple majority to two thirds of the members of each chamber). To this, it must be added that the Congress can only either to approve the treaty submitted by the president, or to reject it. It can not introduce amendments to it, modifying its content. In this regard, Congress may only suggest the formulation of reservations (when it is possible according to the international law) or the introduction of interpretative declarations (art. 54 no. 1).

This institutional frame sets two main (official) mechanisms for the IGs to try to influence Foreign Policy decisions. The first is to make direct contact with policy makers (and negotiators) during the bargain process of the treaties, using the regular channels the law provides. In some negotiations, like most about Free Trade Agreements, a special mechanism is implemented, the so called "room next door" (Bull 2008; Gamboa 2013). In this, the IGs representatives follow the negotiations from a space that is next to that in which they are being held. Then, they can interact with authorities in real time, expressing their preferences and concerns with regard to the course of the negotiations.

The second is to participate during the parliamentary discussion. Once a treaty is signed, the Executive submits it to the Parliament for the ratification process. To enter into force, the treaty in question must be approved by both chambers. The process begins with the discussion in the first chamber (known as chamber of origin), ${ }^{6}$ where it is first analyzed by an specialized committee (normally the

\footnotetext{
${ }^{6}$ With few exceptions, the constitution allows that the discussion can begin either in Senate or in the Chamber of Deputies.
} 
Committee of Foreign Affairs), and then by the assembly. If the treaty is approved by the first chamber, it passes to the other. Here the same procedure applies.

The stage of committee discussion provides the opportunity for IGs to participate and express their opinion with regard to the content of the treaties. The House Rules of each chamber regulate the access of IGs to the sessions, giving ample space for any IG (or private persons) that want to express their opinions to do so (Gamboa et. al. 2016: 150). The interventions of MPs and IGs are registered, so that there is an official record of them.

\section{Data and Method}

As we stated before, in this working paper we have two related objectives. On the one hand, we seek to describe IGs participation in the legislative process of Foreign Policy bills, and, on the other hand, to analyze IGs position regarding those bill proposals. In order to achieve these two objectives, this research is based on publicly available information. Data sources and methods used are described in what follows.

a) Interest Groups' Participation. To analyze IGs participation in the legislative decision making process on matters of Foreign Policy, we built an original data base with information related to the main characteristics of those processes. The data used was obtained from documents elaborated by Chilean Congress, known as Historia de la Ley, which provides an extensive and detailed account of the legislative process that every bill underwent until its final approval.

First, using information provided by Congress, we identified the bill proposals related to Foreign Policy that were approved between 1990 and 2014, according to the Senate's website. In other words, we considered every international treaty that required legislative approval in the first five governments after transition to democracy. We identified 590 bill proposals that fulfilled those requirements. For every bill proposal, then, we collected the following information: title, date in which the proposal started and finished its legislative process, type of treaty, with whom the treaty was signed, and every IG that participated in the legislative discussion. Furthermore, we gathered publicly available information to identify the type of group and the policy domain in which they are expected to develop their lobby activities more11 frequently. 
Groups were classified, following Gamboa et al (2016), in one the following categories: (a) Business groups, including businesses, and business associations; (b) Labor groups, including unions and associations that represent the interests of workers; (c) Citizen groups, including all those groups created for the defense and promotion of particular interests; (d) Professional groups, including professional associations, research institutions and think tanks; and (e) Public institutions, including those public institutions that are related to the State, but are not directly part of the executive or legislative powers.

b) Preference Attainment. As we mentioned before, preference attainment is a methodology develop to study IGs influence in the decision---making process, which is based in the comparison of IGs ideal point and the content of the approved bill. It requires, therefore, information regarding the content of the treaties under consideration and IGs position about them.

We selected 28 treaties that had IG participation in their legislative process: 14 of them are Free Trade Agreements, and the other 14 were randomly selected among the other treaties signed by Chile. These 28 treaties represent the $4,7 \%$ of all the treaties considered by Congress between 1990 and 2014, and the 32,2\% of the treaties where there was IGs participation in the legislative debate. We design this form of treaty selection because it allows us to compare IGs influence in different types of treaties and, particularly, in Free Trade Agreements, which is one of the main objectives of this working paper.

For each of these 28 treaties, and using information provided by Historia de la Ley, we analyze the position expressed by IGs, regarding the contents of each treaty under consideration in the legislative debate. We register a total of 225 opinions, which were coded as in favor of the treaty, against the treaty and as agreement with objections. With this information, we analyzed which types of groups, and under what circumstances, show more favorable opinions with the contents of the treaties. In other words, which groups gets what they want from them. 


\section{Results}

\section{A. Overview. Foreign Policy and International treaties, Chile 1990-2014}

Before we present the data on participation and influence, we will provide general information with regard to the international treaties Chile has subscribed in the period. First, according to Table 1, Chile signed 590 treaties in this period of 24 years, that is, an average of 24,6 per year. At the same time, however, it must be noted that the "intensity" of the Chilean activity in the international stage is not balanced considering the different presidential terms. In effect, the average of treaties per year in considerably higher (above 30) for the two first governments after democratic restoration, Aylwin $(37,3)$ and Frei $(31,8)$, and much lower during the three following: Lagos (23,8); Bachelet (20), and Piñera $(6,7)$.

Table1.Chile: InternationalTreaties(1990---2014).

\begin{tabular}{|l|c|c|}
\hline & N & Percentage \\
\hline President & & $25,3 \%$ \\
\hline Aylwin (1990---1994) & 149 & $32,4 \%$ \\
\hline Frei (1994---2000) & 191 & $24,2 \%$ \\
\hline Lagos (2000---2006) & 143 & $13,6 \%$ \\
\hline Bachelet (2006---2010) & 80 & $4,6 \%$ \\
\hline Piñera (2010---2014) & 27 & $100 \%$ \\
\hline Total & 590 & \\
\hline
\end{tabular}

Source: Authors' own construction, using data obtained from www.congreso.cl.

Second, Table 2 shows the distribution of the treaties by foreign partner. Almost one third of them are multilateral treaties, while the two most "important" partners are Europe $(28,8 \%$ of the treaties) and Latin America $(24,7 \%)$. With other regions, the amount of treaties is significantly lower. Nevertheless, this does not necessarily mean that for Chile those regions are not important. For example, Chile has not signed a great amount of treaties with Asian countries (maybe only the necessary to regulate what is needed), but many of them are important trade partners for Chile, like Japan or China. In this sense, to sign a higher number of treaties is not 11 always a measure of closeness or distance between countries. 
Table 2. International Treaties: Chilean Partners.

\begin{tabular}{|l|c|c|c|c|c|c|}
\hline & Aylwin & Frei & Lagos & Bachelet & Piñera & Total \\
\hline Multilateral & $30,2 \%$ & $28,3 \%$ & $37,8 \%$ & $37,5 \%$ & $22,2 \%$ & $32,0 \%$ \\
\hline Latin America & $32,2 \%$ & $28,3 \%$ & $23,1 \%$ & $31,2 \%$ & $37,0 \%$ & $28,8 \%$ \\
\hline Europe & $22,1 \%$ & $30,4 \%$ & $25,2 \%$ & $16,2 \%$ & $22,2 \%$ & $24,7 \%$ \\
\hline Southeast Asia & $5,4 \%$ & $3,1 \%$ & $2,8 \%$ & $5,0 \%$ & $7,4 \%$ & $4,1 \%$ \\
\hline North America & $4,0 \%$ & $3,7 \%$ & $2,8 \%$ & $1,2 \%$ & & $3,1 \%$ \\
\hline Asia & $0,7 \%$ & $2,6 \%$ & $3,5 \%$ & $3,8 \%$ & $3,7 \%$ & $2,5 \%$ \\
\hline Middle East & $2,7 \%$ & $2,1 \%$ & $1,4 \%$ & $2,5 \%$ & $3,7 \%$ & $2,2 \%$ \\
\hline Oceania & $0,7 \%$ & $1,6 \%$ & $2,8 \%$ & $2,5 \%$ & $3,7 \%$ & $1,9 \%$ \\
\hline Africa & $2,0 \%$ & & $0,7 \%$ & & & $0,7 \%$ \\
\hline TOTAL & $100,0 \%$ & $100,0 \%$ & $100,0 \%$ & $100,0 \%$ & $100,0 \%$ & $100,0 \%$ \\
\hline
\end{tabular}

Source: Authors' own construction, using data obtained from www.congreso.cl.

Third, Table 3 contains information about the matters the 590 treaties regulate. We distinguish four categories: a) Economic, which includes all treaties that regulate economic relations. We divide it into two subcategories for analytical purposes (see below). One includes all the treaties that the General Directorate of International Economic Relations (Direcon) of the Chilean Ministry of Foreign Affairs classifies as Free Trade Agreements. These are 18. The other brings together all other economic agreements, like the Economic Cooperation Agreements, the Investments Agreements, or the treaties that deal. i.e. with agricultural measures, taxation or air transport. The second is Cooperation, and includes all international agreements on matters like Security, Science Development, Education, Justice or Environment. The third is Political Relations, grouping all treaties on this matter, like those that regulate border transit, immigration, diplomatic agreements or human rights. The last is Social Policy, which includes the treaties dealing with issues like agreements on labor regulation or social insurance. 
Table 3. Chile, International Treaties $1990-20014$ by Topic.

\begin{tabular}{|l|c|c|}
\hline & $\mathrm{N}$ & $\%$ \\
\hline Economy & 187 & 31,7 \\
\hline Cooperation (non-economic) & 173 & 29,3 \\
\hline Political Relations & 162 & 27,5 \\
\hline Social Policy & 53 & 9,0 \\
\hline Other & 15 & 2,5 \\
\hline Total & 590 & 100 \\
\hline
\end{tabular}

Source: Authors' own construction, using data obtained from www.congreso.cl.

The table provides interesting information with regard to the priorities of Chilean diplomacy since 1990. In particular, it suggests that the "economic diplomacy" and the "cooperation diplomacy" have concentrated the efforts in the period. In effect, economic agreements account for $31,7 \%$ of the 590 included in the database, agreements subscribed by Chile since 1990, (a much higher percentage than that of political treaties) followed by cooperation treaties $(29,3 \%)$. These data, moreover, are consistent with the analysis of Klaveren (2011), who also underscores the relevance of these themes for Chilean Foreign Policy. However, as Klaveren also suggests, Chilean diplomacy have also other important concerns, like the relation with the neighbor countries, activity that does not necessarily materialize in written agreements.

\section{B. Interest Groups and Chilean Foreign Policy. Participation Trends 1990-2014}

This section discusses IGs participation in Foreign Policy. To do this, as we explained before, we collected data regarding IGs interventions in parliamentary discussion about international treaties agreed between the Chilean government and foreign partners. In particular, we present data regarding general trends in participation, and how IGs participation is distributed according to group types and matters under discussion, paying special attention to IGs participation in Foreign Trade policy.

With respect to IGs participation, Table 4 shows that in only $87(14,7 \%)$ out of 590 international treaties, one or more IGs assisted to Congress to express their 14 opinion about them. In those 87 bill proposals, a total of 173 IGs participated, with 
an average of 2,1 proposals per group. The minimum number of projects in which an IG participated was 1, and the maximum was 21 treaties proposals. In more detail, a $71,1 \%$ of IGs assisted to the discussion of just 1 project, and 13,3\% participated in 2 discussions. Only 6 groups $(2,9 \%)$ participated in the discussion of 9 or more treaties proposals.

Table 4. IGs Participation in Foreign Policy.

\begin{tabular}{|l|c|c|}
\hline & $\mathrm{N}$ & Total \\
\hline With groups & 87 & $14,7 \%$ \\
\hline Without groups & 503 & $85,3 \%$ \\
\hline Total & 590 & $100,0 \%$ \\
\hline
\end{tabular}

Source: Authors' own construction, using data obtained from www.congreso.cl.

This information shows, therefore, that Foreign Policy is not a major area of interest to IGs. This result, moreover, is consistent with information compiled by the authors in other research (Gamboa et el 2014), that analyzed IGs participation in 571 bill proposals that were discussed in Congress between 2006 and 2014. According to that data, in $83 \%$ of the bills related to Foreign Policy, no IG took part in the discussion. Furthermore, Foreign Policy also shows the lowest IGs participation as compared to other areas of public policy: an average of 0,69 groups per proposal participated in foreign policy, while in bills related to fishing had an average of 10,5 groups, education shows an average of 8,9 or health and average of 8,9 . Only in proposals related to Human Rights and Defense IGs participation is lower (0,19 and 0,08 groups respectively).

Even in this case, with low levels of participation, we need to ask about how that participation is distributed, both with respect to the type of groups and to the different issues of the treaties. Regarding group types, the evidence in Table 5 clearly points out that business IGs are the main actor in the legislative discussion visà-vis other types of groups. And this result holds when we consider both the number of discrete groups (173) and the total number of registered interventions in Congress (357).

In effect, when we consider discrete groups, results in Table 5 show that Business IGs are the ones that participate, by far, more in the legislative discussion: 14 Business IGs are 102 out of 173, representing the 59\% of total groups. They are 
followed, in terms of number of groups participating, by Citizens groups, which represent the $15,6 \%$ of the total. Other types of groups have a representation of less than $10 \%$ each.

Table 5. Participation by Groups Type.

\begin{tabular}{|l|c|c|c|c|}
\hline & \multicolumn{2}{|c|}{ Discrete Groups } & \multicolumn{2}{c|}{ Interventions by Group type } \\
\hline & $\mathbf{N}$ & $\mathbf{\%}$ & $\mathbf{N}$ & \% \\
\hline Business & 102 & 59,0 & 239 & 66,9 \\
\hline Labor & 14 & 8,1 & 22 & 6,2 \\
\hline Citizens & 27 & 15,6 & 28 & 7,8 \\
\hline Professionals & 17 & 9,8 & 45 & 12,6 \\
\hline Public Institutions & 5 & 2,9 & 10 & 2,8 \\
\hline Other & 8 & 4,6 & 13 & 3,7 \\
\hline Total & 173 & 100 & 357 & 100 \\
\hline
\end{tabular}

Source: Authors' own construction, using data obtained from www.congreso.cl.

On the other hand, when we consider the number of interventions, as Table 5 demonstrates, the differences between groups are even larger. Out of 357 registered interventions, $66,9 \%$ are due to business IGs. They are followed by professional groups $(12,6 \%)$, and the rest of the groups have a marginal participation, with less than $10 \%$ of the interventions each.

This pattern of unequal participation, is consistent with the general one identified by Gamboa et al (2016: 153), which also show that business IGs are the type of group that participate more, showing a large difference with other groups. According to the authors, business IGs represent $41,5 \%$ of groups and $39 \%$ of interventions. In the results reported in this work, however, this pattern is even more pronounced, showing that in the case of Foreign Policy representation of interest is even more unequal.

Now, considering this general pattern, what happens when we analyze independently treaties on economic matters and treaties about other issues? The data of Table 6 are very clear. On the one hand, they show that when the parliamentary discussion is about economic matters, business IGs have an overwhelming participation and are responsible for $85 \%$ of the interventions. Other groups have a minor participation, with the exception of professional groups 14 (9,3\% of interventions). 
Table 6. Participation by Type of groups. Interventions

\begin{tabular}{|l|c|c|c|c|c|}
\hline & \multicolumn{2}{|c|}{ Economic } & \multicolumn{2}{c|}{ Non-Economic } & Total \\
\hline & $\mathrm{N}$ & $\%$ & $\mathrm{~N}$ & $\%$ & \\
\hline Business & 210 & 85 & 29 & 26,4 & 239 \\
\hline Labor & 7 & 2,8 & 15 & 13,6 & 22 \\
\hline Citizens & 3 & 1,2 & 25 & 22,7 & 28 \\
\hline Professionals & 23 & 9,3 & 22 & 20,0 & 45 \\
\hline $\begin{array}{l}\text { Public } \\
\text { Institutions }\end{array}$ & 2 & 0,8 & 8 & 7,3 & 10 \\
\hline Other & 2 & 0,8 & 11 & 10,0 & 13 \\
\hline & 247 & 100 & 110 & 100 & 347 \\
\hline
\end{tabular}

Source: Authors' own construction, using data obtained from www.congreso.cl.

We can also add more specific data regarding participation exclusively in the discussion of Free Trade Agreements, which we consider as part of the treaties related to economic matters. First, FTAs concentrate 179 interventions, that is, $51,6 \%$ of all interventions done between 1990 and 2014 in foreign policy, and a $72,5 \%$ of interventions related to economic issues. Therefore, all in all, trade policy is by far the issue that attracts more IGs participation regarding Foreign Policy. Additionally, if we consider groups participation within FTAs, business groups are again the most active group type, being accountable for $85,2 \%$ of interventions.

On the other hand, however, when non---economic issues are discussed, the pattern of participation is different. As is shown in Table 6, business IGs are the one with more interventions vis---à---vis other groups (representing a $26 \%$ of the total), but are closely followed by professional groups (20\%) and citizen groups $(22,7 \%)$. These results suggest that, as mentioned before, the participation pattern changes in the expected direction, showing a more balanced one, as has been also argued in other cases (Gamboa et al 2016; Bindenkrantz et al, 2014).

\section{Preferences and decisions. Who gets what they want in Chilean Foreign Policy}

In this last section we present the results obtained from our study about who gets what they want in Chilean Foreign Policy. As we mentioned before, this study uses preference attainment as the method for comparing and analyzing IGs expressed preferences in the parliamentary debates about treaties. In this context, therefore, when preferences expressed by groups are in agreement 
with the final decision -the final text of the treaty--- we understand that they are getting what they want.

The main findings of this study are as follows. First, as can be observed in Table 7, IGs express, in general, favorable opinions regarding the contents of the treaties. In effect, from a total of 225 coded opinions for 28 treaties, the $76,4 \%$ of them are in agreement with the proposed contents, while a 13,3\% expressed a general agreement, but with main objections to some of their specific contents. Lastly, only a $10,2 \%$ of the opinions are negative.

Table 7. Opinions expressed by IGs

\begin{tabular}{|c|c|c|c|c|c|c|}
\hline & \multicolumn{2}{|c|}{ TOTAL } & \multicolumn{2}{|c|}{ FTAs } & \multicolumn{2}{|c|}{ Other Treaties } \\
\hline & $\mathrm{N}$ & $\%$ & $\mathrm{~N}$ & $\%$ & $\mathrm{~N}$ & $\%$ \\
\hline In favor & 172 & 76,4 & 126 & $75,9 \%$ & 46 & $78,0 \%$ \\
\hline $\begin{array}{l}\text { With } \\
\text { Objections }\end{array}$ & 30 & 13,3 & 25 & $15,1 \%$ & 5 & $8,5 \%$ \\
\hline Oppose & 23 & 10,2 & 15 & $9,0 \%$ & 8 & $13,6 \%$ \\
\hline Total & 225 & 100,0 & 166 & $100,0 \%$ & 59 & $100,0 \%$ \\
\hline
\end{tabular}

Source: Authors' own construction, using data obtained from www.congreso.cl.

This pattern is reproduced when we compare the opinions given regarding FTAs with those expressed about other types of treaties. As can be seen in Table 7, the levels of agreement are similar in each case, existing no statistically significant differences.

Second, when we consider the opinions expressed by group type, the pattern previously described remains the same -that is, in general, opinions are favorable to treaties. The only exception can be observed in the case of labor groups, whose opinions are in a $25 \%$ of the cases favorable, a third of them show objections, and a $42 \%$ are unfavorable to the sign of treaties. In any case, the participation of labor groups is minor, making it difficult to generalize these results to the positions labor unions express about Foreign Policy in general. 
Table 8. Opinions expressed by IGs by group type

\begin{tabular}{|l|c|c|c|c|c|c|}
\hline & \multicolumn{5}{|c|}{ Other } & Total \\
\hline In favor & $91,3 \%$ & $79,6 \%$ & $66,7 \%$ & $25,0 \%$ & $75,0 \%$ & $76,4 \%$ \\
\hline $\begin{array}{l}\text { With } \\
\text { objections }\end{array}$ & $8,7 \%$ & $11,7 \%$ & $16,7 \%$ & $33,3 \%$ & $25,0 \%$ & $13,3 \%$ \\
\hline Oppose & $0,0 \%$ & $8,6 \%$ & $16,7 \%$ & $41,7 \%$ & $0,0 \%$ & $10,2 \%$ \\
\hline $\mathrm{N}$ & 23 & 162 & 24 & 12 & 4 & 225 \\
\hline$\%$ & $100,0 \%$ & $100,0 \%$ & $100,0 \%$ & $100,0 \%$ & $100,0 \%$ & $100,0 \%$ \\
\hline
\end{tabular}

Source: Authors' own construction, using data obtained from www.congreso.cl.

Third, in order to evaluate the relative influence of different groups and other factors that can affect that influence, we run a logistic regression. The dependent variable is a dummy that indicates favorable positions to the treaties $(1=$ in favor; 0 = oppose and with objections). Independent variables are the following: a dummy variable that indicates the type of treaty ( $1=$ FTAs, $0=$ other treaties $)$, the type of group expressing their opinion (two dummy variables, one that indicates business IGs and the other Labor IGs), a variable that measures the length of the legislative process, and the number of bills in which each group participates -as an indication of expertise in lobby activities. In the last two variables we used the natural $\log$.

Table 9: Logistic Regression on influence

\begin{tabular}{|c|c|c|c|c|c|c|}
\hline & $B$ & E.T. & Wald & $\mathrm{Gl}$ & Sig. & $\operatorname{Exp}(B)$ \\
\hline FTA & ,588 & ,722 & ,664 & 1 & 415 & 1,801 \\
\hline Business & ,569 & ,460 & 1,535 & 1 & 215 & 1,767 \\
\hline Workers & $---1,853$ & 786 & 5,556 & 1 & ,018 & 157 \\
\hline In_length & ,705 & 263 & 7,201 & 1 & ,007 & 2,023 \\
\hline $\begin{array}{l}\text { In_number } \\
\text { of bills }\end{array}$ & ,393 & 180 & 4,803 & 1 & ,028 & 1,482 \\
\hline Constant & $---3,714$ & 1,869 & 3,949 & 1 & ,047 & ,024 \\
\hline$N$ & 225 & & & & & \\
\hline Chi2 & $32,350 * * *$ & & & & & \\
\hline Pseudo R2 & 0,205 & & & & & \\
\hline
\end{tabular}

$* * * \mathrm{p}<0,001$

Source: Authors' own construction, using data obtained from www.congreso.cl. 
Results indicate that, controlling for other factors, IGs get what they want from Foreign Policy when the legislative process is longer, and when they have more experience in lobby activities. Moreover, the results also reveal that business IGs do not have more influence than other group types, ceteris paribus, while groups representing labor unions and workers are less likely to get what they want. Finally, the results also show that, the likelihood of success or influence in the legislative discussion regarding foreign policy is not related to the type of treaty. In effect, controlling for other factors, groups obtain what they want in all types of treaties.

\section{Concluding remarks}

This research has provided with ample and interesting evidence in relation to the initially proposed objectives. It constitutes a contribution to the study of Chilean Foreign Policy in general, and to the way civil society relates to it. Moreover, given the research methodology used, its results can be compared to the ones obtained in other cases.

On the one hand, with respect to participation, the evidence highlights the relevance of several characteristics of the Chilean political system. First, it demonstrates that Foreign Policy is a policy area in which IGs participation is minor, and that they attempt to intervene in the legislative process of only a few $(14,5 \%)$ treaties. Additionally, as we mentioned before, foreign policy is one of the policy areas with the lowest participation average.

Second, the distribution of participation according to group type is highly uneven. In effect, business IGs concentrates a large percentage of the lobby activity done in this policy area, both in the total number of groups participating and in the number of interventions. In fact, this distribution pattern is even more uneven than the one observed when we consider other policy areas, as argued by previous research.

Third, and despite this pattern, when we consider the distribution of participation according to issues, we observe an important change in the levels of participation by groups. Results show that there is more balance between business, professional, and citizen groups when the proposals being discussed are non- 19 -economic. 
Fourth, the research also reveals another characteristic of IGs participation, which is related to the way that participation among groups is distributed within economic treaties. In particular, we observe that the subgroup of FTAs concentrate more than $72 \%$ of the interventions made by IGs in economic---related treaties. This result confirms that free trade is the most important issue that mobilizes IGs participation on matters of foreign policy.

On the other hand, the preference attainment analysis also provided with interesting results. First, it shows that when IGs intervene in the parliamentary discussion of treaties, they do it to express support to the initiative. In effect 3 out of 4 interventions made by IGs are in favor of the approval of the treaty. A similar pattern emerges when we consider the subsample of FTAs, with the exception of labor IGs, which in general present a critical position to them. Second, our regression analysis could not provide a conclusive result regarding which type of group see their preferences better represented. This is probably associated to the distribution of preferences expressed by groups (mostly in favor of treaties), but it is different to results obtained in other studies (Jacobs \& Page 2005), and counterintuitive in light of participation data. The likelihood of IGs success is not related either to the type of treaty under discussion.

Together, these results suggest two groups of questions to address in future research. The first one is related to what explains the low level of IGs participation in Foreign Policy. According to the evidence presented, and informal communications with practitioners and experts, there are at least three factors that could contribute to answer this question. First, as we discuss previously, IGs in Chile exhibit a low level of participation in the legislative debate; therefore, it would be no surprise to find that participation in this policy area is also low.

Second, it is possible that people and, more importantly, groups, do not perceive foreign policy as a relevant area to their own well---being, providing them with no incentives to participate. In fact, public opinion surveys done in Chile have consistently showed that, since the return to democracy, foreign policy is not one of the top priorities in policy making. This suggests that the case of Chile might be different to other countries, like the US or those that are part of the EU, where 20 relations with other countries might be perceived as more relevant by different 
political actors.

Third, it is also possible, as suggested by Dür (2008), that IGs give more relevance and prioritize other types or forms of participation to express their opinions, like direct contact with the authorities, and therefore concentrate their efforts in those types of actions. Research on FTAs negotiations has shown that direct contact with authorities has been a used strategy by Chilean IGs, particularly of business groups (Gamboa 2013).

The second issue relevant for future research is related to how to better study the issue of influence. As we said, our evidence is inconclusive with respect to which groups win and which groups loose in the decision making process. However, this result only analyzes the level of congruence between IGs preferences and the result, in a context where $75 \%$ of interventions are favorable to the treaties. Therefore, it might happen that the attempts to influence in policy making through their presence in the parliamentary debate are considered less effective than attempts to influence in other stages of the policy making process. In this context, case studies using process tracing as their main research strategy, and that focus at the stage of treaty negotiations (like the "room next door") might be better suited to provide a more definitive answer to the question of influence, and to what are the determinants of each group' influence in the final decision.

\section{VII. . References.}

Baroni, Laura, Brendan Carroll, Adan Chalmers, Luz Muñoz and Anne Rasmussen. 2014. "Defining and classifying interest groups". Interest Groups \& Advocacy 3(2): 145---159.

Baumgartner, Frank and Beth Leech. 1998. Basic Interests. The importance of Groups in Politics and in Political Science. Princeton: Princeton University Press.

Baumgartner, Frank and Beth Leech. 2001. "Interests niches and policy bandwagons: Patterns of interests groups involvement in national politics". Journal of Politics 63 (4): 1191---1213

Baumgartner, Frank, Jeffrey Berry, Marie Hojnacki, David Kimball and Beth Leech. 2009. Lobbying and Policy Change. Who wins, who loses and why. London: The University of Chicago Press.

Binderkrantz, Anne, Peter Christiansen, and Helene Pedersen. 2014. "A Privileged 
Position? The Influence of Business Interests in Government Consultations". Journal of Public Administration Research and Theory 24: 879---896.

Bull, Benedicte. 2008. "Policy Networks and Business Participation in Free Trade Negotiations in Chile". Journal of Latin American Studies 40 (2): 195---224.

Direcon (Dirección de Relaciones Económicas). 2009. Chile: 20 años de negociaciones comerciales. Santiago: Direcon--- BID.

Dür, Andreas. 2008. "Measuring Interest Influence in the EU: A note on methodology". European Union Politics 9: 559---576.

Dür, Andreas and Gemma Mateo. 2012. "Who lobbies the European Union? National interest groups in a multilevel polity". Journal of European Public Policy 19 (7): 969---987.

Dür, Andreas and Dirk De Bièvre. 2008. "The Question of Interest Group Influence". In Kohler---Koch, Beate, Dirk De Bièvre, and William Maloney (eds.), Opening EU--- Governance to Civil Society Gains and Challenges. Mannheim: Connex, 25---43.

Gamboa, Ricardo. 2013. "Interest Groups in Foreign Trade Negotiations: Chile, Colombia and Peru in a comparative perspective". In http://www.wti.org/institutional--- cooperation/seco---wti--project/publications/.

Gamboa, Ricardo, Carolina Segovia and Octavio Avendaño. 2014. "Mapping Group Interest's Representation in the Legislative Process: Chile 2006---2014". Paper presented at the XXXIV Congress of the Latin American Studies Association, Chicago, May 21---24.

Gamboa, Ricardo, Carolina Segovia and Octavio Avendaño. 2016. "Interest Groups and Policymaking: Evidence from Chile, 2006---2014". Interest Groups and Advocacy 5: 141---164.

Godwin, Ken, Scott Ainsworth and Erik Godwin. 2013. Lobbying and Policy Makinng. The public pursuit of private Interests. London: Sage.

Jacobs, Lawrence and Benjamin Page. 2005. "Who influences U.S. Foreign Policy?".

American Political Science Review 99(1): 107---123.

Keohane, Robert and Helen Milner (eds). 1996. Internationalization and Domestic Politics.

Cambridge: Cambridge University Press.

Klüver, Heike. 2012. "Biasing politics? Interest group participation in European policy--- making". West European Politics 35:1114-33.

Klüver, Heike. 2013. "Lobbying as a collective enterprise: winners and losers of 
policy formulation in the European Union. Journal of European Public Policy 20(1): 59---76

Helboe, Helene. 2013. "Is measuring interest group influence a mission impossible? The case of interest group influence in the Danish parliament". Interest Groups \& Advocacy 2 (1): 27---47.

Herreros, Sebastián. 2010. "Chile". In Capling, Ann and Patrick Low, Government, Non--- State Actors and Trade Policy Making. Negotiating Preferentially or Multilaterally. New York: CUP. (Kindle edition)

Hojnacki, Marie; Kathleen Marchetti; Frank Baumgartner; Jeffrey Berry; David Kimball; and Beth Leech. 2015. "Assessing Business Advantage in Washington Lobbying. Interest Groups \& Advocacy advance online publication, 2 June 2015; doi:10.1057/iga.2015.3

McConrmick, James (ed). 2012. The Domestic Sources of American Foreign Policy: Insights and Evidence. Lanham: Rowman \&Littlefied.

Klaveren, Alberto v. 2011. "La política exterior de Chile durante los gobiernos de la Concertación (1990---2010)". Revista de Estudios Internacionales 169: 155---172.

Mahoney, Christine. 2007. "Lobbying Success in the US and in the European Union".

Journal of Public Policy 27 (1): 35---56.

Milner, Helen. 1997. Interests, Institutions, and Information: Domestic Politics and International Relations. Princeton, NJ: Princeton University Press.

Rogowski, Ronald. 1989. Commerce and Coalitions. Princeton: Princeton University Press.

Shapovalova, Natalia. 2015. Advocacy and interest group influence in EU foreign policy. Thesis Submitted for the Degree of $\mathrm{PhD}$ at the University of Warwick. http://wrap.warwick.ac.uk/77666/1/WRAP_THESIS_Shapovalova_2015.pdf

Voltonini, Benedetta. 2013. Lobbying in EU foreign policy---making towards the Israeli--- Palestinian conflict: Exploring the potential of a constructivist perspective. Thesis submitted to the Department of International Relations of the London School of Economics for the degree of Doctor of Philosophy, London, July 2013. http://etheses.Ise.ac.uk/751/1/Voltolini_Lobbying_EU_foreign_policy---making.pdf

Yackee, Jason and Susan Yackee. 2006. A bias towards business? Assesing interest group influence on the US bureaucracy. Journal of Politcs 68 (1): 128---139. 